\title{
Cocoa (Theobroma cacao L.) harvest and postharvest in Tabasco, Mexico
}

Pérez-Flores, Julián ${ }^{1}$; Mendoza-Hernández, José Rodolfo $\mathrm{H}^{1}{ }^{1}$, Cleomé Abel ${ }^{2}$, Córdova-Ávalos, Víctor ${ }^{{ }^{*}}$

${ }^{1}$ Colegio de Postgraduados, Campus Tabasco, Cárdenas, Tabasco. ${ }^{2}$ Institut National du Café d'Haiti (INCAH/MARNDR), Damien, Route Nationale, MARNDR, Puerto Príncipe, Haití.

*Corresponding author: vcordova@colpos.mx

\section{ABSTRACT}

Objective: To characterize the harvest and postharvest of the cocoa management system at La Chontalpa, Tabasco, Mexico

Design/methodology/approach: The study took place in the towns of Francisco Trujillo Gurría and Ernesto Aguirre Colorado de Huimanguillo, Tabasco, Mexico. The study was descriptive and accounted for 51 producers and those responsible for the cocoa profit centers. Producers were chosen through targeted sampling. A survey on their harvest and postharvest was applied, in addition to direct assessment in plantations and profit centers.

Results: The cocoa harvesting is manual. The producers cut the ripe and almost ripe fruits, do not store and $58.8 \%$ of them do not make "quebraderos" with the fruits. With a "machete" cut the fruit in half and manually extract the grains. The fresh grains are sold at a profit. The cocoa is then fermented in wooden boxes, dried artificially, natural, or in a combined way, and packed in "yute" bags for sale. Profit centers do not keep track of their grain origin and make no selection or determine product quality.

Study limitations/implications: All producers harvest in the same way, but the processes during post-harvest could differ at different collection centers.

Findings/conclusions: The harvest of cocoa fruits at different maturity and the lack of storage causes a heterogeneous fermentation. The humidity level during the drying process is empirically determined.

Key words: Harvest, cacao, fermentation, drying

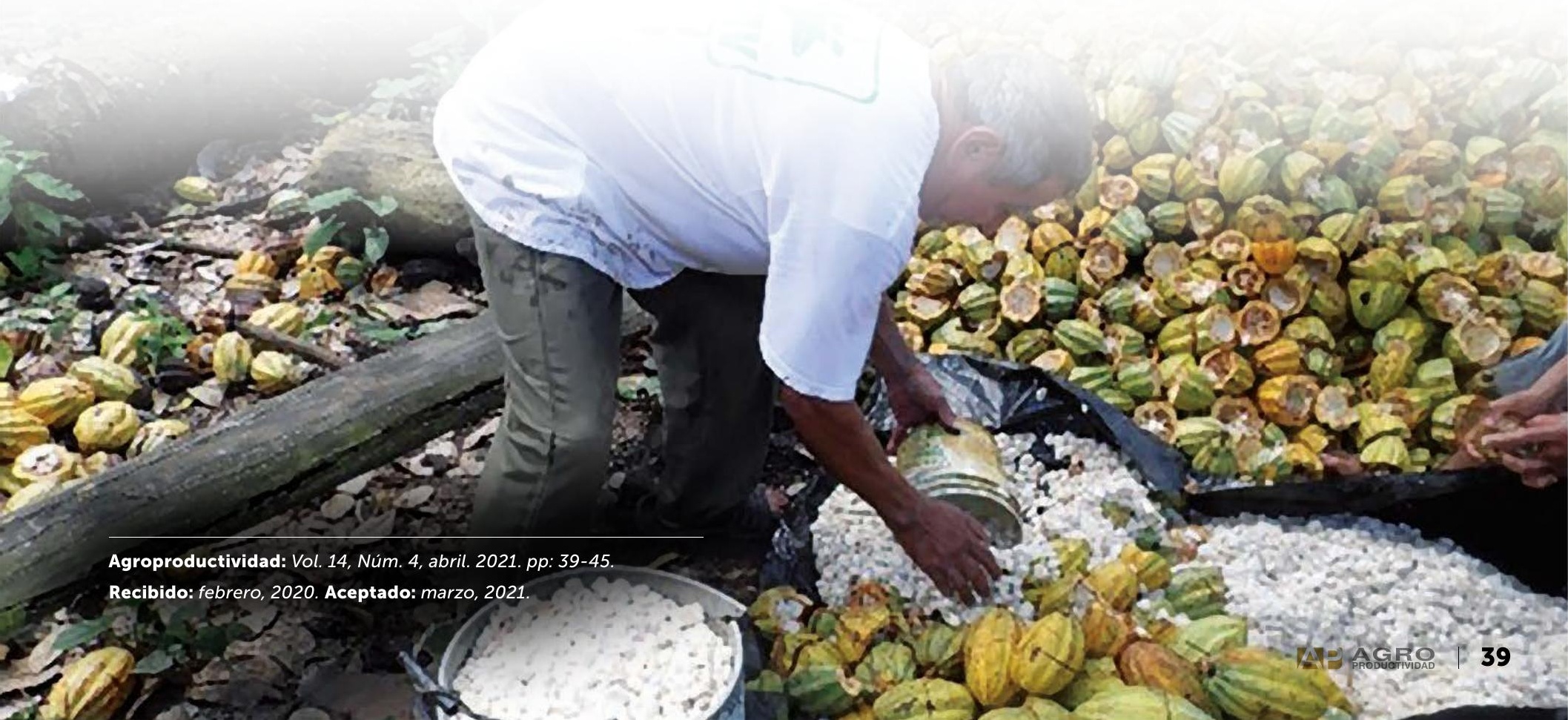




\section{INTRODUCTION}

T

he harvest and postharvest, in addition to the cocoa genotype (Theobroma cacao L.) determine the quality of the cocoa beans (Jiménez, 2003). The harvest consists of cutting, opening of the fruit (pods) and extracting their grains. Postharvest handling includes the fermentation, drying, classification, packaging and storing the cocoa beans in collection or profit centers (Moreno and Sánchez, 1989). The fermentation and drying of the grains constitute the step previous to its commercialization and industrialization. Fermented and dried cocoa is easy to transport, store and of better-quality product (Jiménez, 2003).

The quality of the cocoa produced in Mexico is not high (not cataloged as "fine" or "aroma cocoa"). In the 1930s, high-quality creole cacao (ICCO, 2012) grown in Mexico, was replaced for lower-quality more productive varieties. Currently, these are no longer as productive, due to age, disease and poor agronomic management.

Only ripe pods should be cut for harvest. Maturity can be indicated by the color, which is yellow or orangeyellow depending on the genotype. The harvest of overripe pods with germinated grains produces chopped grains, susceptible to the fungi attack, affecting their commercialization, the flavor of the chocolate produced with them and overall puts its innocuity at risk (Enríquez, 2004). Harvesting immature pods affect postharvest because undeveloped grains do not contain enough pulp and sugars for fermentation (Enríquez, 2004). The fermentation and drying of cocoa beans during post-harvest handling determine their flavor and aroma characteristics, which are the basis of the quality established by the international market (González et al., 2012). Variations in fermentation and drying result in differences in the final quality of the product (Ortiz de Bertorelli et al., 2009). With that in mind, the objective here was to characterize the harvest and postharvest management in two cocoa profit centers.

\section{MATERIALS AND METHODS}

The study took place at Francisco Trujillo Gurría and Ernesto Aguirre Colorado towns (Villages C-32 and C-40 respectively) of Huimanguillo, Tabasco, Mexico.

The study was descriptive and included the producers and managers of cocoa processing centers. The producers included in the study were chosen through a sample directed among those attending an assembly called by the Ejidal Commissariat (local authority) and the President of the Local Association of Cacao Producers (ALPC) of each community. Two surveys were used as a research technique. One on regard the field harvest ( $n=25$ C32 producers, and $n=26$ C40 producers), directly in the plantations and during the harvest time. The questionnaire covered, from how cocoa is cut and the cocoa beans extracted, to the way it is sold and its destination.

The post-harvest survey was applied to the Presidents of the ALPCs directly at the cocoa processing centers. The questionnaire ranged from the general characteristics of the benefit in terms of the date of establishment, number of workers and area of influence, to aspects of the quality control and destination of the obtained grain. In addition to the surveys, the obtained data were complemented and corroborated by direct assessment of the plantations, facilities, process conditions and product handling.

\section{RESULTS AND DISCUSSION Harvest}

Producers harvest cocoa with knives and machetes (Figure 1a). They cut the fruits at physiological maturity and those near to it, colloquially called "sazones". $41.2 \%$ of the producers have "quebraderos" (Figure 1b), identified as sites within the plantation where the harvested cocoa is collected before the extraction of the beans. In these quebraderos, producers with the help of a machete cut the fruit in half and extract the cocoa beans by hand without detaching the funicle. $100 \%$ of the producers mentioned that, to obtain a kilo of fresh cocoa, 10 to 13 fruits are needed, and that a bucket full of cocoa beans (Figure 1c) weighs between 20 and $23 \mathrm{~kg}$. 41.2\% of the visited producers have their trees numbered and can identify those most productive and disease resistant. Also, they record the fruits per plant at the time of harvest. This is important because a participatory genetic selection program could be emplaced (Alonso-Baez and Aguirre-Medina, 2009).

Once the slimy cocoa beans (fresh) are extracted theses are taken to the collection center of the local Association (ALPC). Sometimes producers sell to intermediaries because the Association might not have the cash to pay for the product at the time of delivery (Córdova-Ávalos et al., 2008). 


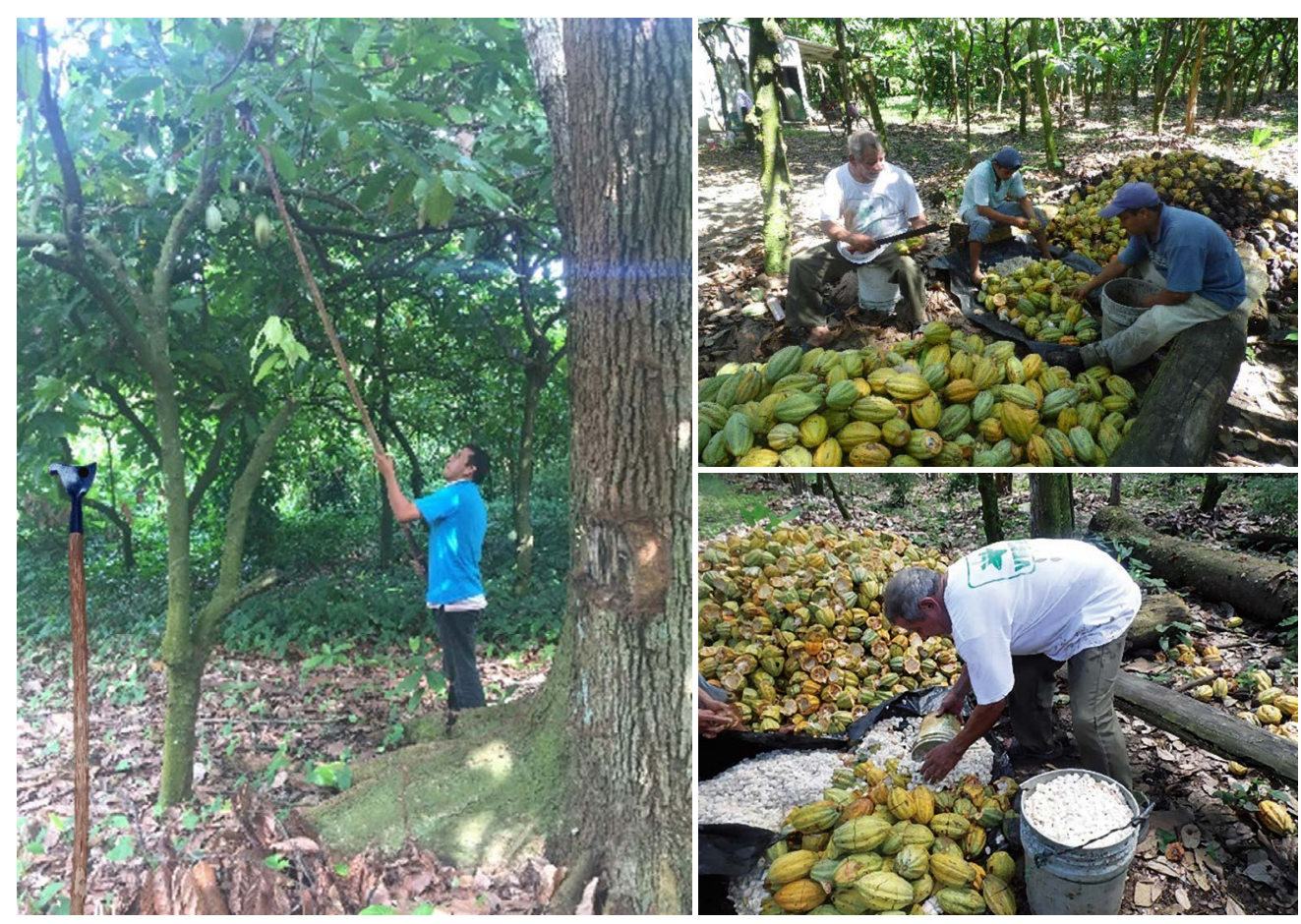

Figure 1. a: Usage of a blade (luco) to harvest cocoa. b: "Quebradero" of cocoa fruits. c: Preparation of a bucket of cocoa for sale.

From the interviewed producers, $41 \%$ report testing the scales. That it is, the producers test them by weighing themselves before their cocoa. $47 \%$ of the visited plantations obtain a dry cocoa production of $395.3 \mathrm{~kg}$ $\mathrm{ha}^{-1}, 47 \%$ obtain less than $232.5 \mathrm{~kg} \mathrm{ha}^{-1}$ and $6 \%$ obtain up to $837.2 \mathrm{~kg} \mathrm{ha}^{-1}$. These yields are high compared to the $372 \mathrm{~kg} \mathrm{ha}^{-1}$ reported by Díaz et al. (2013) for six municipalities in Tabasco and five in Chiapas. However, if we consider that the average cocoa production in Tabasco is $460 \mathrm{~kg} \mathrm{ha}^{-1}$ (SIAP, 2019), the average production (464.9 $\mathrm{kg} \mathrm{ha}^{-1}$ ) for the assessed towns is within the state average.

With regard to technification, only $2 \%$ of the plantations are installing drip irrigation; the rest is seasonal. 23.5\% of the visited producers organically manage their plantations, compost and implement 70 to $80 \%$ of the management recommended by Alonso-Baez and Aguirre-Medina (2009) for cultivation: pruning, discarding diseased fruits, diseased branches, apply copper sulfate to ease moniliasis (Moniliophthora roreri), and manually control weeds.

The productive period of cocoa plantations has been estimated to be between 25 to 30 years (Yao et al., 2015). In this study, $88 \%$ of the plantations are over 30 years old, and therefore some producers are trying to renew their plantations through government support programs or their means. These producers are planting new cocoa varieties to renew and rehabilitate their plantations. The rehabilitation of plantations was indicated by Díaz et al. (2013) as the highest priority measure to reactivate cocoa production in Mexico.

The discouragement of the producers during the harvest is usually due to the theft of fruits, the misalignment of prices, pests and diseases. The theft of fruits cannot be controlled and causes the cocoa to be harvested immaturely and not at the "quebraderos" as it was used to. Immature cocoa fruits affect the final quality of the product because it does not adequately ferment. The absence of quebraderos affects plantation sustainability. After the extraction of cocoa beans, the shell and funiculus remained there, which accounted for up to $80 \%$ of the cocoa fruit. The husk and funiculus already decomposed (cascarilla) were incorporated as fertilizer in the plantations.

The cocoa price mismatch was observed because in the evaluated harvest season (2016-2017) the price per kilogram of fresh cocoa varied by $26 \%$ in relation to the final price. Córdova-Ávalos et al. (2008) reported a 25\% fluctuation in the initial and final price of a kilogram of fresh cocoa for the 1999-2000 harvest in Huimanguillo, Tabasco. This means that the price mismatch in cocoa is a constant every year and that it is not the leaders of the associations and the UNPC who determine the price of fresh cocoa, as stated by Córdova-Ávalos et al. (2008).

Pests such as squirrels and birds (Melanerpes aurifrons) cause direct and indirect damage. No methods for bird control were applied. Hunters are hired to control squirrels who charge US \$2.00 per hunted squirrel. These mammals feed on the grain, exposing fruit residues (Figure 2) that serve as an inoculum for fungal diseases such as monilia and black spot (Phytophthora palmivora). These diseases have caused the abandonment of plantations by reducing their production by up to $80 \%$, 


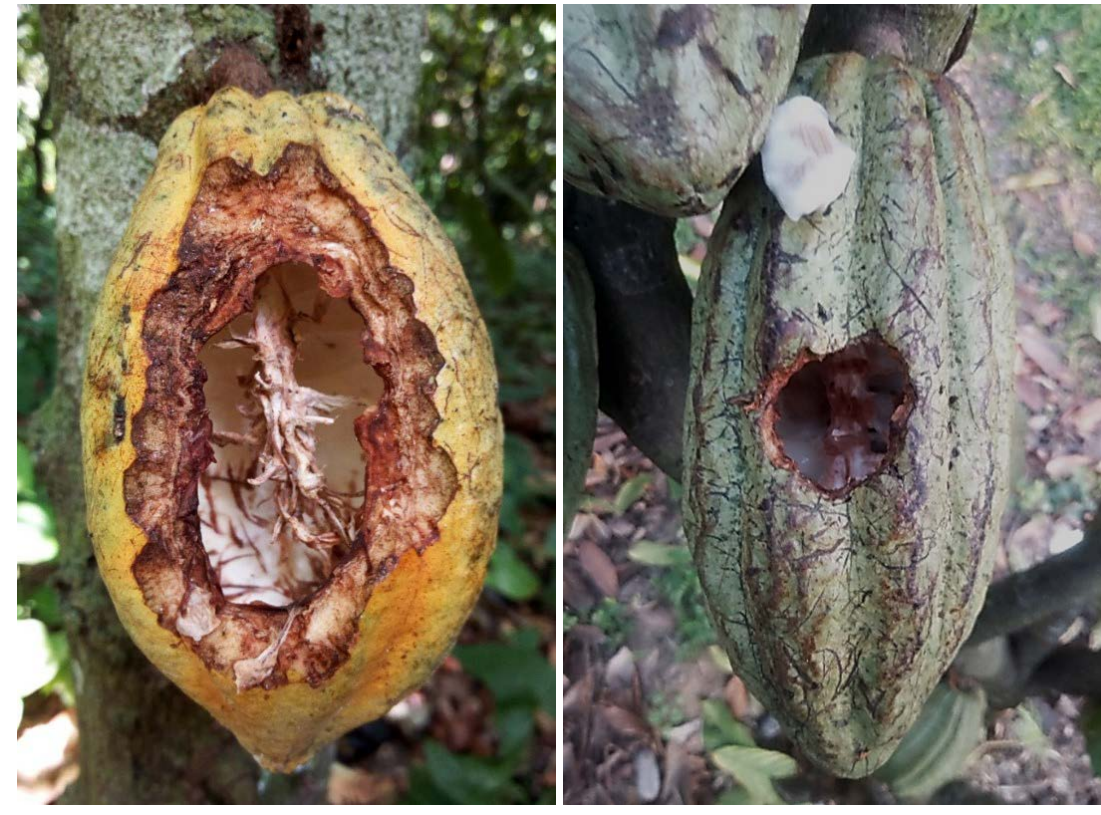

Figure 2. Cacao fruit damaged by squirrels (left) and birds (right).

making the crop unaffordable. As mentioned by Díaz et al. (2013) from 2000 to 2011, cocoa production in Mexico decreased $43.7 \%$ due to the attack of moniliasis, among other factors.

\section{Postharvest and cocoa collection center characterization}

The post-harvest of cocoa begins in the fields and ends in the ALPC collection centers. Postharvest begins the moment the cocoa pods are removed from the tree. It ends when the grain is dry and ready for sale or industrial processing. Postharvest includes the fermentation and drying processes, which largely determine the quality of chocolate.

In the present study, the producers do not pre-condition the cocoa pods, and once they are cut from the tree, they are split with a machete and their grains are extracted by hand. Afoakwa (2011) recommends splitting the cocoa pods with a wooden pillar or a machete. Preconditioning is the storage of harvested cocoa pods for a period before pod opening and bean fermentation (Afoakwa et al., 2014). The storage of the cocoa pods before its opening and grains extraction influences their fermentation (Kongor et al., 2013) and improves the quality of chocolate produced with it (González et al., 2012). The fermentation, drying, selection, packing and storage of the cocoa bean for sale, constitute the benefits process of the cocoa bean. The characteristics and infrastructure of the profit centers are shown in Table 1.
In relation to the type and material of construction, both profit centers are closed cement buildings. This is important because the fermentation process requires constant climatic conditions. Likewise, these profit centers have office areas and equipment, but do not have hygrometers or a guillotine to test grain cutting. This test and moisture determination are essential to assess the physical quality of the fermented grain. Regarding the type of cocoa received, both profit centers receive fresh cocoa (Rodríguez et al., 2012).

\section{Characteristics of the fermentation, drying and storage of cocoa}

At the profit centers, once the fresh beans are received, they are transferred to wooden boxes for fermentation (Figure 3). Fermentation takes place for $8 \mathrm{~d}$. The fermentation of cocoa beans in boxes has been classified as a low uniformity method since it results in an incomplete use of sugars and a high presence of defective beans (Guehi et al., 2010). The fermentation process in these centers is inadequate since the producers do not classify the grains before their fermentation, which does not favor a homogeneity of the fermented grains. On the other hand, the lack of instruments for moisture determination and cutting tests makes it difficult to know if the beans are well fermented.

The drying of cocoa consists of the loss of moisture from the grains that go from $60 \%$ to $<8 \%$ for their safe storage (Afoakwa et al., 2014). At the C40 Town, only artificial drying is used, in C32 it is combined with natural drying (Figure 4). However, in the latter, the drying capacity is lower. In both profit centers, dry cocoa is packed in 50 to $60 \mathrm{~kg}$ jute bags and stored until marketed.

\section{Quality control and regulatory aspects}

Both centers have no certification to process cocoa, do not classify the beans, and do not perform cutting tests. The beans are sold without information of their origin. There is no process for packaging and tracking the grains (the bags does not keep information of the batch from the producer, fermentation, drying and packaging). A traceability system allows the chocolate industry to know how the beans were processed (Saltini et al., 2013). 
Table 1. Characteristics of postharvest cocoa handling in two towns of The Chontalpa Plan, Tabasco, Mexico.

\section{Collection center characteristics}

Town

Foundation year

Type of bought cocoa

Working months

Construction type

Construction material

Office supplies

Moisture meter and guillotine

Balances

Incorporation as a company

\begin{tabular}{|c|}
\hline Francisco Trujillo Gurria (C-32) \\
\hline 2005 \\
\hline Fresh \\
\hline Nov-Jan y April-Jun \\
\hline Closed \\
\hline Concrete \\
\hline Furniture and files \\
No \\
Si \\
No
\end{tabular}

Ernesto Aguirre Colorado (C-40)

\section{Collection center capacity}

\begin{tabular}{l|c|c}
\hline Number of workers & 10 & 14 \\
\hline Installed capacity to ferment * & 50 & 140 \\
\hline Used capacity to ferment * & 10 & 15 \\
\hline Installed drying capacity * & 10 & 32 \\
\hline Used capacity for drying * & 4 & 32 \\
\hline Cocoa received * & 18 & 35 \\
\hline Producers served & 70 & 170 \\
\hline Average area per producer (ha) & 1.5 & 1.5 \\
\hline
\end{tabular}

\section{Fermentation}

Do you ferment your cocoa?

Fermenters type

Days to ferment

\section{Drier type in use}

\begin{tabular}{l} 
Natural drying \\
\hline Time (days) \\
\hline Turning frequency \\
\hline Artificial drying \\
\hline Time (hours) \\
\hline Daily drying capacity (ton)
\end{tabular}

Yes
Wooden boxes
7

Yes

\begin{tabular}{c} 
Yes \\
\hline Wooden boxes \\
\hline 8
\end{tabular}

1940

Fresh

Nov-Jan y Feb- April

Closed

Concrete

Furniture and files No

Si

Si

$\mathrm{Si}$

\section{Storage}

Do you store your product?

Infrastructure type

Do you classify grains and do cutting test?

Each bag keeps the lote information from the producer, ferment, drying and packaging?

\begin{tabular}{|c|c|} 
Yes \\
3 \\
$2 \mathrm{~h}$ \\
Yes \\
12 a 16 \\
1.5 \\
\hline
\end{tabular}

\begin{tabular}{|c} 
No \\
\hline \\
\hline Yes \\
\hline 24 a 36 \\
\hline 4 \\
\hline
\end{tabular}

\section{Regulatory aspects}

Are you certified to benefit cocoa?

What company does the certification?

\begin{tabular}{|c|c} 
Yes \\
Concrete \\
No \\
No \\
\hline
\end{tabular}

\begin{tabular}{c} 
Yes \\
\hline Concrete \\
\hline No \\
\hline No
\end{tabular}

\section{Final product and its destination}

\begin{tabular}{l}
\hline Standard type? \\
\hline Who do you sell your cocoa to? \\
\hline Product destination \\
${ }^{*}$ sem $^{-1}$ per week; ${ }^{* *}$ Agroindustrias Unidas de Cacao S.A. de C.V \\
${ }^{* *}$ National Union of Cocoa Producers.
\end{tabular}

\begin{tabular}{c|c} 
No & No \\
\hline AMCO $* *$ & - \\
\hline Yes & Yes \\
\hline National market & NUCP *** \\
\hline
\end{tabular}

*** National Union of Cocoa Producers. 
According to the Mexican standard for quality control of cocoa beans (NMX-FF-118-SCFI-2014), both centers produce "First-class fermented and dried" cocoa. The characteristics of top-quality cocoa are a minimum of $60 \%$ well-fermented beans, humidity of less than $8 \%$ and the absence of atypical odors such as smoky or moldy (Fowler and Coutel, 2017).

\section{Commercialization and destination of the grain}

The profit center of the ALPC of town C32 sells the dry cocoa to the Agroindustrias Unidas de

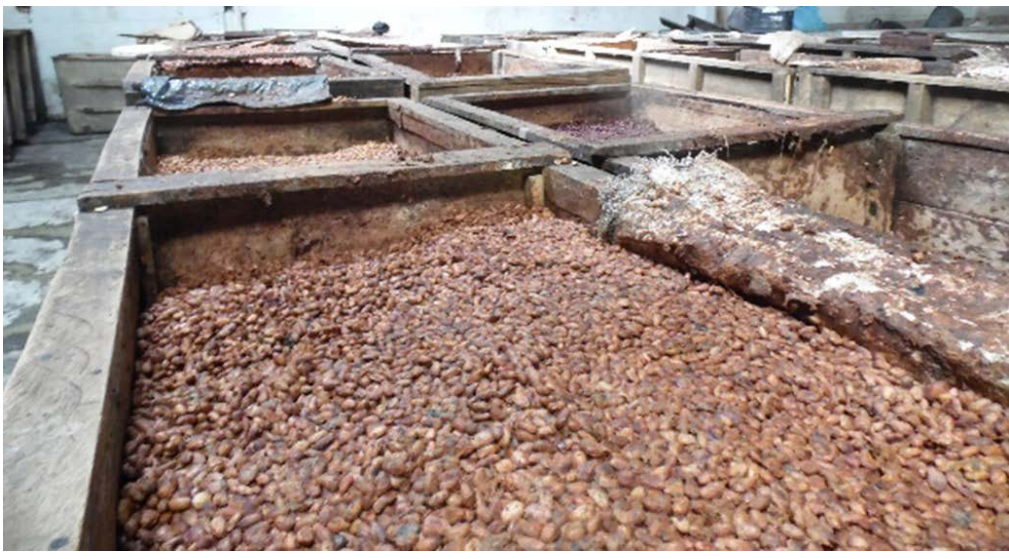

Figure 3. Fermentation of cocoa in wooden boxes
Cacao S.A. de C.V. company (AMCO), that at the

C40 town sells to industry and the UNPC. The UNPC sells the grains to national and foreign agro-industrial companies. It was determined that the price of the $\mathrm{kg}$ of fresh cocoa varies from US\$ 0.50 to US\$ 0.75, the profit centers in turn sell the $\mathrm{kg}$ of dry processed cocoa between US\$2.20 to US\$2.40.

\section{CONCLUSIONS}

At the assesses localities the cocoa harvest is manual. Producers harvest ripe fruits and due to cocoa theft, seasoned (immature) fruits are also harvested. Producers do not precondition (store) their fruits prior to the manual extraction of the cocoa beans. Immature fruits and a lack of preconditioning affect cocoa fermentation. The fermentation of the grain takes place in wooden boxes and is not homogeneous. Drying is artificial, natural or combined. The dry, unsorted grain is packed in jute bags for sale. Profit centers do not keep a record of the origin of the cocoa beans, nor do they perform cutting or moisture tests on the grains to determine the quality of the product. The centers are limited regard the adoption of methods and technologies to optimize the fermentation and drying processes. However, its physical spaces are convenient to carry out these processes.

\section{ACKNOWLEDGMENTS}

To the cocoa producers of Poblado C-32 and C-40 for their access to their plantations and for collaborating with the interviews, and to the Presidents of the ALPC and heads of the Cocoa Collection (Benefit) Center, Mr. José del Carmen Torres and Utiliano G. López, of the C-32 and C-40, respectively.

\section{REFERENCES}

Afoakwa E. 2011. Chocolate science and technology, John Wiley \& Sons. 526 p.
Afoakwa E., Kongor J.E., Budu A.S., Mensah B., Takrama. 2014. Changes in some biochemical qualities during drying of pulp preconditioned and fermented cocoa (Theobroma cacao L.) beans African Journal of Food, Agriculture, Nutrition and Development 2(3):1-8. http://dx.doi.org/10.15226/jnhfs.2014.00121

Alonso-Baez M., Aguirre-Medina J.F. 2009. Manual de producción de cacao. INIFAP. Tuxtla Chico, Chiapas. 109 p.

Córdova-Ávalos V., Mendoza-Palacios J.D., Vargas-Villamil L. Izquierdo-Reyes F., Ortíz-García C.F. 2008. Participación de las asociaciones campesinas en el acopio y comercialización de cacao (Theobroma cacao L.) en Tabasco, México. Universidad y Ciencia 24(2):147-158.
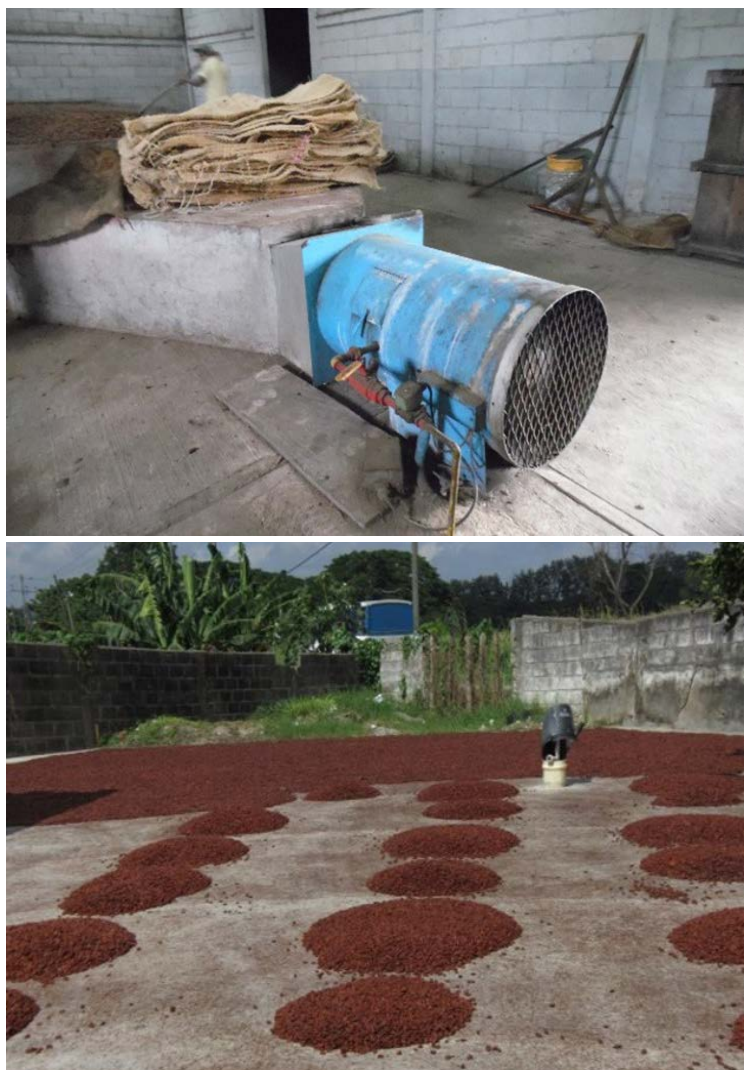

Figure 4. Equipment for artificial drying of cocoa, jute bags for packaging and natural drying of cocoa 
Díaz-José O., Aguilar-Ávila J., Rendón-Mendel R., Sontoyo-Cortés V.H. 2013. Current state of and perspectives on cocoa production in Mexico. Ciencia e Investigación Agraria. 40(2):279-289.

Enríquez G. 2004. Cacao orgánico, guía para productores ecuatorianos. INIAP. Manual No. 54. Quito, Ecuador. pp. 39 - 294.

Fowler M.S., Couttel F. 2017. Cocoa beans: from tree to factory. In: Beckett ST, Fowler MS, Ziegler GR (eds.) Beckett's Industrial Chocolate Manufacture and Use, Fifth Edition, Wiley Blackwell Publishing Ltd. pp: $9-49$

González M.Y., Pérez S.E., Palomino C.C. 2012. Factores que inciden en la calidad sensorial del chocolate, Actualización en Nutrición 13(4):314-331.

Guehi T., Dabonne S., Ban K., Kedjebo K., Zahouli I. 2010. Effect of turning beans and fermentation method on the acidity and physical quality of raw cocoa beans. Advance Journal of Food Science and Technology. 2(3):163-171.

ICCO (2012). The world cocoa economy: past and present. London, 43 p.

Jiménez J. 2003. Prácticas del Beneficio del cacao y su calidad organoléptica. Mimeografiado. INIAP, Estación Experimental Tropical Pichilingue. Quevedo, Ecuador. 16 p.

Kongor J.E., Takrama J.F., Budu A.S., Mensah-Brown H., Afoakwa E.O. 2013. Effects of fermentation and drying on the fermentation index and cut test of pulp pre-conditioned Ghanaian cocoa (Theobroma cacao) beans. Journal of Food Science and Engineering. 3(11):625-634.

Moreno L., Sánchez A. 1989. Beneficio del cacao. Fundación Hondureña de Investigaciones Agrícolas, Fasc. № 6, pp. 14-16.

NMX-FF-118-SCFI-2014. Productos agrícolas no industrializados- Cacao en grano (Theobroma cacao L.) Especificaciones y métodos de prueba. Normas mexicanas. Dirección Nacional de Normas. 2014.

Ortiz de Bertorelli L., Gervaise R.G.L., Graziani de F.L. 2009. Influencia de varios factores sobre índices físicos del grano de cacao en fermentación. Agronomía Tropical. 59(1):81-88.

Rodríguez C., Escalona B., Contreras R., Orozco A., Jaramillo F., Lugo C. 2012. Effect of fermentation time and drying temperature on volatile compounds in cocoa. Food chemistry. 132(1):277-288.

Saltini R., Renzo A., Stina F. 2013. Optimizing chocolate production through traceability: A review of the influence of farming practices on cocoa bean quality. Food Control. 29(1):167-187.

SIAP (Servicio de Información Agroalimentaria y Pesquera). 2019. Cierre de la producción agrícola por cultivo SAGARPA. México. Disponible en línea en: http://www.siap.gob.mx (página web visitada 29 de noviembre 2019).

Yao P., Ahoutou K., Issiaka Y. 2015 Manuel Technique de Cacao Culture Durable. Al'attention du technicien. Le Conseil du Café-Cacao. Francia. 166 p.

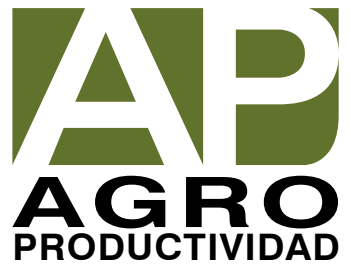

